\title{
Open access: changing the way chemistry is published
}

\author{
Jan Kuras*, Bailey Fallon \\ From 7th German Conference on Chemoinformatics: 25 CIC-Workshop \\ Goslar, Germany. 6-8 November 2011
}

Publishing research in open access (OA) journals ensures free and permanent unrestricted online access to peer-reviewed articles [1], and increased visibility for articles and increased potential citations. In addition, authors retain copyright to their work, and data can be redistributed, reused and translated freely [2]. Removing barriers to accessing and sharing data is beneficial for researchers and their institutions, as well as funders, educators and the public.

Having had success in biomedical and physics publishing, support continues to grow for open access in chemistry, in particular amongst the cheminformatics community. The range of benefits for authors and institutions makes open access a viable and effective publishing model for chemistry research.

This poster provides an overview of the benefits of open access, and compares the OA model to traditional subscription journal publishing.

Published: 1 May 2012

\section{References}

1. Berlin Declaration on Open Access to Knowledge in the Sciences and Humanities. 2000 [http://oa.mpg.de/files/2010/04/berlin_declaration.pdf], T. Others \& V Clever.

2. Creative Commons copyright license. [http://creativecommons.org/ licenses/].

Publish with ChemistryCentral and every scientist can read your work free of charge

"Open access provides opportunities to our colleagues in other parts of the globe, by allowing anyone to view the content free of charge."

W. Jeffery Hurst, The Hershey Company.

- available free of charge to the entire scientific community

- peer reviewed and published immediately upon acceptance

- cited in PubMed and archived on PubMed Central

- yours - you keep the copyright

Submit your manuscript here:

http://www.chemistrycentral.com/manuscript/

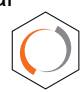

Chemistry Central 